Old Dominion University ODU Digital Commons

Finance Faculty Publications

Department of Finance

2011

\title{
What Influences the Changes in REIT CEO Compensation? Evidence from Panel Data
}

John M. Griffith

Old Dominion University

Mohammad Najand

Old Dominion University

H. Shelton Weeks

Follow this and additional works at: https://digitalcommons.odu.edu/finance_facpubs

Part of the Business Administration, Management, and Operations Commons, $\underline{\text { Corporate }}$ Finance Commons, and the Economics Commons

\section{Repository Citation}

Griffith, John M.; Najand, Mohammad; and Weeks, H. Shelton, "What Influences the Changes in REIT CEO Compensation? Evidence from Panel Data" (2011). Finance Faculty Publications. 17.

https://digitalcommons.odu.edu/finance_facpubs/17

\section{Original Publication Citation}

Griffith, J. M., Najand, M., \& Weeks, H. S. (2011). What influences the changes in REIT CEO compensation? Evidence from panel data. The Journal of Real Estate Research, 33(2), 210-232. 


\title{
What Influences the Changes in REIT CEO Compensation? Evidence from Panel Data
}

Authors

\author{
John M. Griffith, Mohammad Najand, and \\ H. Shelton Weeks
}

Abstract

\begin{abstract}
This study examines what influences the changes in REIT CEO compensation using the following performance measures: average three-year total returns to shareholders, market value added, Tobin's q, and change in funds from operations. The impact of managerial power on the change in compensation is also examined. The empirical evidence indicates that firm performance and size do not influence the change in CEO salary, while risk, tenure, title, ownership, and age have significant impacts. Bonuses are not influenced by risk, size, or CEO power; however, they are influenced by performance. Option awards are affected by performance and CEO power.
\end{abstract}

Agency problems and costs arise because of the "separation of ownership and control" of a corporation. Stockholders face two sources of agency problems. First, partial ownership of the firm by managers may induce the managers to consume non-pecuniary benefits (perquisites) beyond those that a sole owner would consume. The second problem is underinvestment (residual loss). Both are costly and difficult to solve. Jensen and Meckling (1976) show that as the owner manager lessens her ownership, agency costs (monitoring, bonding, and residual loss) increase monotonically. Boards of directors try to minimize these agency problems through compensation contracts.

Executive compensation has been the subject of many studies. Most have focused on industrial firms. ${ }^{1}$ Chopin, Dickens, and Shelor (1995) study real estate investment trust (REIT) executive compensation and examine the influence board structure has on the level of CEO compensation. They also examine the relationship between the level of compensation of top REIT executives and standard accounting measures, such as the change in revenue, total assets, net income, EPS, and unexpected profits. Hardin (1998) examines Equity REITs (EREITs) and finds that size, number of years since the EREIT's initial public offering (IPO), dollar amount of dividends paid to senior executives and percentage of stock owned by senior executives have a significant influence on the level of senior executive compensation. Scott, Anderson, and Loviscek (2001) examine the impact of market-based performance measures on REIT executives' 
total incentive compensation. Pennathur and Shelor (2002) examine the relationship between changes in CEO compensation, specific performance measures of the REIT industry, and stock returns. Pennathur, Gilley, and Shelor (2005) explore the association between REIT CEO stock-based compensation and industry-specific performance measures. Gosh and Sirmans (2005) examine how a board's structure influences CEO compensation packages.

This study investigates whether the following influence the changes in REIT CEO compensation: (1) CEO power (tenure, title, interlock relationship, and ownership), (2) the size and complexity of the firm, (3) firm risk and CEO risk aversion, and (4) firm performance. ${ }^{2}$ Four measures of CEO performance are employed. The first performance measure used is the average three-year total return to shareholders (TR3YR). The next measure is market value added (MVA), defined as the difference between the market value of capital items and capital invested. The third measure used is Tobin's q. Although MVA and Tobin's q are used in the corporate finance literature as measures of managerial performance, they have rarely been used in previous REIT research studies. The final performance measure is the change in funds from operations $(C F F O)$, which is used extensively in the REIT literature. The influences various REIT and CEO characteristics have on the change of CEO compensation are also examined.

Five forms of REIT CEO compensation are used to examine the influences of firm performance: (1) change in CEO salary (CSalary), (2) cash bonuses (BONUS), (3) the change in CEO salary plus bonus $(C T C C)$, (4) the change in CEO total compensation (CTDC), and (5) stock options granted (BLKVAL). Bonuses and option income are in themselves changes each year, that is, they can be zero if a level of performance is not achieved. An unbalanced panel data set is used to capture both the time-series and cross-sectional effects. Previous work on REIT executive compensation has chiefly looked at compensation data on a cross-sectional basis. The findings of this study reveal that performance and size do not influence CSalary, while risk, tenure, title, ownership, and age have significant effects. Contrary to previous findings, BONUS is not influenced by risk, CEO power, or size. Not surprisingly, BLKVAL is affected by firm performance (TR3YR and $C F F O$ ). The awards are also influenced by CEO power (tenure and title).

The following section presents a review of the REIT compensation literature and the background for the paper. The data and methodology are discussed next, followed by an analysis of the empirical results. The paper concludes with closing remarks.

\section{Literature Review}

The body of literature that examines various aspects of the REIT industry continues to expand significantly in terms of depth and breadth and there is an abundance of research on executive compensation; however, there has been little 
work on REIT CEO compensation. ${ }^{3}$ Chopin, Dickens, and Shelor (1995) model REIT executive cash-based compensation as a function of revenue and unexpected profits. They find unexpected profits and revenue are positively and significantly correlated with executive compensation when they group all executives. Furthermore, their results show revenue and size are positively correlated with the level of executive compensation. However, when they classify executives by office, they do not find a consistent relationship between unexpected profits or revenue and the level of CEO compensation.

Hardin (1998), in his study of EREITs, is the first to use measures of performance specific to the REIT industry. The industry-specific variables he uses are the time elapsed since the EREIT's IPO, senior managements' ownership, dividends paid to executives, whether the executive founded the EREIT, and a dummy for the property type. He finds size, number of years since the IPO, dollar amount of dividends paid to senior executives, and percentage of stock owned by senior executives influence the level of senior executive compensation. Conversely, he finds that founder status and property type have no influence on the level of executive compensation. He concludes that his findings highlight the need for industry-specific compensation models. Scott, Anderson, and Loviscek (2001), on the other hand, focus on incentive cash compensation. They carve out incentive cash compensation by subtracting base compensation from total compensation. They model incentive compensation as a function of total shareholder return, size, time since the REIT's IPO (age), and type of property managed. They find market performance has a significantly greater impact on incentive compensation than firm size. Specifically, incentive compensation is elastic to performance, but only unit elastic to size. In contrast to the findings of Hardin (1998), their results indicate that age does not influence executive compensation.

Pennathur and Shelor (2002) test the relationship between the change in CEO cash compensation (CCCC) and the following: stock returns, changes in real estate investment, change in funds from operations, CEO age, earnings per share, whether the property is self-managed, and property type for the years 1994-1999. For the years 1994-1996, they find no relationship between CCCC and any of their independent variables. They attribute this to the small sample size for the period of study. They find a positive relationship between CCCC and the previous year's stock returns for the years 1997-1999 and a negative relationship between CEO age and CCCC. In addition, for this period they find CCCC is not influenced by earnings per share (EPS) or property type, regardless of whether the REIT is self-managed. For the years studied, they also find that prior years' performance significantly influences CEO raises. Using the same performance and control variables, Pennathur, Gilley, and Shelor (2005) examine the relationship between CEO stock-based compensation and stock returns, EPS, changes in real estate investment, and changes in funds from operations. They use age, property management, and property type as control variables and find that CEOs receive larger option awards when the REIT has greater growth opportunities, funds from operation, and EPS. Further, they find the riskier the REITs' investments, as 
measured by the variability of returns, the larger the CEO option awards. Unexpectedly, they find a negative relationship between option awards and REIT stock performance and size. They suggest that the negative relationship between option awards and stock performance is because REITs that suffer losses during periods of high growth utilize larger stock option awards as a way of motivating CEOs. Contrary to Pennathur and Shelor (2002), they find that CEO age has no influence on option awards. Similarly, Ghosh and Sirmans (2003) examine the impact of board composition and monitoring on REITs' performance. They find greater representation by external directors on REIT boards improves performance. Ghosh and Sirmans (2005) find that CEO compensation is higher when their boards are weak and conclude that REIT board structure is ineffective in monitoring CEOs.

A more recent study by Feng, Ghosh, and Sirmans (2007) examines director compensation by REITs. Their findings indicate higher equity-based compensation for directors is positively related to higher financial performance. While they show a positive relationship between equity-based director compensation and the use of an independent nominating committee, they find no significant relationship with board size, use of outside directors, CEO duality, or CEO tenure and ownership. Ertugrul, Sezer, and Sirmans (2008) examine corporate hedging activities by REITs. They conclude that the CEO's cash compensation and wealth sensitivity to stock return volatility are significant determinants of REIT derivative use. Ghosh, Harding, Sezer, and Sirmans (2008) investigate the relationship between the announcement of REIT stock repurchases and the use of managerial stock options. They find a positive relationship between managerial option holdings and repurchase announcements.

This study expands this area of research by focusing on the REIT CEO pay-forperformance relationship. Several important questions about the change in REIT CEO compensation are addressed, including the question of how CEO ownership, the number of positions held by the CEO, the size and complexity of the firm, firm risk, and CEO performance affects the changes in the different types of compensation.

Data and Methodology

\section{Data}

The data for this study were obtained from four sources: (1) compensation and return data from SNL Financial, (2) compensation data from Standard and Poor's ExecuComp database (2000-2006), (3) return data (stock market data) from the Center for Research in Security Prices (CRSP), and (4) Standard and Poor's Research Insight. Compensation, ownership, and performance information was obtained from SNL Financial for 232 REITs from 2000 to 2006, resulting in 1,624 observations. The ExecuComp database contains CEO compensation from the 
Exhibit 1 | Descriptive Statistics for REIT CEO Compensation, REIT Performance, Managerial Power, and Control Variables

\begin{tabular}{|c|c|c|c|c|}
\hline Variable & Mean & Min & Max & Std. Dev. \\
\hline Salary ${ }^{a}$ & $\$ 387.68$ & 0 & $\$ 1,143.64$ & $\$ 211.85$ \\
\hline BONUS $^{a}$ & $\$ 459.24$ & 0 & $\$ 3,287.59$ & $\$ 473.61$ \\
\hline$T C C^{a}$ & $\$ 847.57$ & 0 & $\$ 3,841.23$ & $\$ 604.43$ \\
\hline$B L K V A L^{a}$ & $\$ 402.734$ & 0 & $\$ 5,011.33$ & $\$ 719.57$ \\
\hline$T D C^{a}$ & $\$ 2,059.93$ & 0 & $\$ 38,253.41$ & $\$ 3,183.28$ \\
\hline CSalary* & $\$ 57.41$ & $-\$ 103.48$ & $\$ 271.14$ & $\$ 233.08$ \\
\hline CTCC $^{a}$ & $\$ 479.93$ & $-\$ 1,286.54$ & $\$ 1,823.61$ & $\$ 912.63$ \\
\hline $\operatorname{CTDC}^{a}$ & $\$ 748.68$ & $-\$ 3,201.17$ & $\$ 6,715.22$ & $\$ 1,087.38$ \\
\hline TR3YR & $19.14 \%$ & $-16.57 \%$ & $102.64 \%$ & $15.24 \%$ \\
\hline$M V A^{b}$ & $\$ 1,405.61$ & $-\$ 376.82$ & $\$ 11,069.57$ & $\$ 1,683.17$ \\
\hline Tobin's q & 1.19 & 0.69 & 5.34 & 0.88 \\
\hline $\mathrm{CFFO}^{\mathrm{b}}$ & 29.87 & -39.54 & $1,002.36$ & 43.91 \\
\hline Age & 50.91 & 37 & 80 & 8.91 \\
\hline Tenure & 8.87 & 1.29 & 43.20 & 7.47 \\
\hline Ownership & $2.91 \%$ & $0.01 \%$ & $19.8 \%$ & $4.31 \%$ \\
\hline Total Assets ${ }^{\mathrm{b}}$ & $\$ 5,761.94$ & $\$ 308.11$ & $\$ 25,147.26$ & $\$ 4,791.34$ \\
\hline Market Value & $\$ 4,258.37$ & $\$ 203.24$ & $\$ 13,981.67$ & $\$ 2,943.81$ \\
\hline Risk & $1.49 \%$ & $0.73 \%$ & $4.92 \%$ & $0.60 \%$ \\
\hline \multicolumn{5}{|c|}{$\begin{array}{l}\text { Notes: TCC is the total current compensation comprised of salary and bonus; BLKVAL is the } \\
\text { aggregate real value of stock options granted to CEO; TDC is total compensation; CSalary is } \\
\text { change is salary; CTCC is the change in total current compensation comprised of salary and } \\
\text { bonus; CTDC is change in total compensation; TR3YR is the average three-year total returns to } \\
\text { shareholders; MVA is the firm's market value added; Tobin's } q \text { is the ratio of the market value of } \\
\text { the firm's equity and debt to the replacement cost of its assets; Risk is the standard deviation of } \\
\text { stock returns; and CFFO is the change in funds from operations. } \\
\text { a Variables are in thousands of dollars. } \\
\text { b Variables are in millions of dollars. }\end{array}$} \\
\hline
\end{tabular}

S\&P 500, S\&P MidCap 400, and S\&P SmallCap 600 firms. Data were gathered for 57 CEOs for 48 REITs, resulting in an additional 234 observations (20002006). Combining the data collected from SNL and ExecuComp resulted in 1,781 observations for 276 REITs. Those REITs with only one-year's data available were eliminated.

Exhibit 1 contains the descriptive statistics across all years for all the REITs in the sample. ${ }^{4}$ Average CSalary, BONUS, CTCC, CTDC, and BLKVAL are $\$ 57,415$, $\$ 459,243, \$ 479,926, \$ 748,683$, and $\$ 402,734$, respectively. ${ }^{5}$ The average CEO's 
age $(A G E)$, tenure, and percentage of ownership (\%Own) are 51 years old, 9 years, and $2.91 \%$, respectively. ${ }^{6}$ The mean TR3YR, MVA, Tobin's $q$, and CFFO of the sample of REITs is $19.14 \%, \$ 1.41$ billion, 1.19 , and 29.87 million, respectively. The mean REIT size (Total Assets) is $\$ 5.76$ billion and Average Market Value is $\$ 4.26$ billion.

\section{Methodology}

Five different definitions for the dependent variable, the change in CEO compensation, are employed. The first is the change in salary (CSalary) and the second is CEO cash bonus (BONUS). BONUS is a one-time payment based on the prior performance. ${ }^{7}$ Each year's $B O N U S$ is independent of the prior year's $B O N U S$, so BONUS is used rather than change in BONUS. Next, CSalary plus bonus $(C T C C)$ is examined. The fourth definition is the most inclusive and is equal to the change in salary, bonus, restricted stock granted, stock options granted, long-term incentive payouts, and other $(C T D C)$, which includes perquisites, other personal benefits, tax reimbursements, the difference between the price paid for company stock and the market value of the stock for company purchase plans not available to others, and certain deferred compensation. The last definition is the value of stock options granted (BLKVAL) using the BlackScholes model to value these options. Similar to BONUS, BLKVAL is not dependent on the prior year's grant. ${ }^{8}$ Therefore, stock option grants are employed rather than the change in $B L K V A L$. All numbers are adjusted for inflation, and as a result, the unit of analysis is the yearly change in real compensation (the base year is 2006). The individual must have been the CEO of the same company the year before to be included in the data set. Therefore, an observation for the year a person was promoted to CEO is not included.

The empirical model has changes in compensation as a function of: (1) performance, (2) risk, (3) managerial power, and (4) control variables. The following model is used to test the hypotheses:

$$
\begin{aligned}
\text { CComp }_{i t} & =\alpha_{0}+\beta_{1} \text { Performance }_{i t-1}+\beta_{2} \text { Risk }_{i t}+\beta_{3} \text { MPower }_{i t} \\
& +\beta_{4} \text { Controls }_{i t}+e_{i t}
\end{aligned}
$$

where:

CComp $_{i t}=$ The change in compensation in year $t$ for firm $i$;

Performance $_{i t-1}=$ Performance of firm $i$ in year $t-1$;

$R_{i s k_{i t-1}}=$ The standard deviation of stock returns in year $t$ for firm $i$ in year $t-1$;

MPower $_{i t}=$ Managerial power of the CEO for firm $i$ in year $t$; and Controls $_{i t}=\mathrm{A}$ vector of controls in year $t$ for firm $i$ (discussed below). 
The measure of performance is multifold. The primary measure is average threeyear stockholder total returns $(T R 3 Y R)$. This measure makes the implicit assumption that executives are rewarded not only for contemporaneous performance but also for immediate past performance. Three-year returns were chosen over one-year and five-year returns because TR3YR was found to have the most significant influence on the change in compensation. Market value added (MVA) is used to see if there is a positive relationship between wealth maximization and changes in compensation. $M V A$ is defined as the difference between the market value of all capital items and capital invested. $M V A$ measures how much management has increased shareholders' wealth. By maximizing MVA, management is maximizing returns in excess of the cost of invested capital. Tobin's $\mathrm{q}^{9}$ is also used to measure managerial performance. By its construction, Tobin's $q$ provides evidence of whether a firm's management is making positive net present value investments. Tobin's $q$ is the market value of the REIT divided by the replacement cost of total assets. A marginal Tobin's $q$ of less than one is an indication of over-investment (i.e., management has invested in negative net present value projects). A Tobin's $q$ greater than one suggests that management has made value-maximizing investments. The final measure of performance is change in funds from operations (CFFO). This measure is a cash-flow surrogate and has been used extensively in the REIT literature as a measure of performance. Vincent (1999) finds that this measure of performance consistently provides incremental information content. $C F F O$ is expected to have a positive effect on compensation. All definitions of the change in compensation are expected to be positively related to performance. The empirical evidence on this relationship is mixed. Pennathur, Gilley, and Shelor (2005) find a negative relationship between option awards and stock performance, while Pennathur and Shelor (2002) find a significant positive relationship between the CCCC and stock performance and Scott, Anderson, and Loviscek (2001) find a significant positive relationship between incentive cash compensation and stock performance.

Four measures for managerial power are employed. The first, Tenure, is how long an individual has been the company's CEO. The presumption is that the longer a person has served as CEO, the more power that person possesses. The second, Title, a dummy variable, is used to indicate whether the CEO is also the chairman of the board of directors. This serves as an indicator of a CEO's ability to influence compensation policies. The third, Interlock, is a dummy variable indicating whether the CEO is involved in a relationship requiring disclosure in the "Compensation Committee Interlocks and Insider Participation" section of the proxy statement. The last, PctOwn, reflects a CEO's ownership of the firm. The greater the CEO's holdings, the more influence the individual may have over the amount and type of compensation. Han (2006) finds a significant non-linear relationship between REIT insider ownership and REIT value. Thus, insider ownership and the remaining proxies for power are expected to affect REIT value significantly and therefore, affect a CEO's performance-based compensation.

Several REIT and CEO characteristics have been shown to have an impact on the change in CEO compensation; thus, several control variables are employed. Since

\begin{tabular}{l|ll|lllllll} 
JRER & Vol. 3 & 3 & No. & 2 & -2 & 2 & 0 & 1 & 1 \\
\hline
\end{tabular}


the dependent variable is the change in compensation, the size (TASSETS) of the firm is utilized as a control variable in the regressions. Size differentials may reflect differences in executives' abilities (Rosen, 1982; and Rose and Shepard, 1997). Larger firms' CEOs might be expected on average to have greater changes in compensation (Baumol, 1959). YEAR is to control for differences in economic growth, compensation mix, and other potential changes over time. CEO age (Age) is used as a control variable because it may affect a CEO's attitude toward risk (Gibbons and Murphy, 1992; and Smith and Watts, 1992). Age also serves as a proxy for experience (Willis, 1985). It is also possible for Age and Tenure to serve as a proxy for the age of the REIT. Therefore, if Age serves as a proxy for experience or the age of the REIT, it should have a positive effect on CSalary. The models were also run with and without property type dummies to control for possible differences in the compensation between various types of REITs.

An unbalanced panel data set is employed in this study. This approach enables the use of a large number of data points, increasing the degrees of freedom and reducing collinearity among explanatory variables, thus improving the efficiency of econometric estimates. Longitudinal data allow the analysis of a number of important econometric questions that cannot be addressed using cross-sectional or time-series data. Another major advantage of using panel data is that it provides a means of resolving or reducing the effects of omitted or unobserved variables that are correlated with explanatory variables in econometric models. For example, the change in CEO compensation may be correlated with ability or other unobserved variables. If ability and any other unobserved variables remain approximately constant over short time periods, the use of panel data provides a reasonable approach for addressing unobserved heterogeneity. Importantly, when using panel data, a choice must be made between a random effects and fixed effects model. Using a random effects model requires the assumption that there is no correlation between the individual effects. This can result in inconsistency because of the influence of omitted variables. A fixed effects model does not require the assumption of no correlation between the individual effects. In addition, the results of the Hausman Specification Test show that a fixed effects model is appropriate. ${ }^{10}$ Therefore, a fixed effects model is selected over the random effects model for the panel data examined in this study.

\section{Results}

The results for the different definitions of change in CEO compensation are reported in Exhibits 2 through 6. All the models are significant and have high explanatory power. The results are unchanged by the inclusion or exclusion of property type dummies.

\section{Change in Salary}

Exhibit 2 presents the results for CSalary. Previous work on REIT executives' compensation does not segment out salary from total compensation or cash 
Exhibit 2 | Regressions

\begin{tabular}{|c|c|c|c|c|}
\hline \# & 1 & 2 & 3 & 4 \\
\hline Intercept & $\begin{array}{r}-138.12 \\
(0.58)\end{array}$ & $\begin{array}{r}-135.01 \\
(0.50)\end{array}$ & $\begin{array}{r}-133.14 \\
(0.57)\end{array}$ & $\begin{array}{r}-141.52 \\
(0.49)\end{array}$ \\
\hline TR3YR & $\begin{array}{c}0.04 \\
(0.11)\end{array}$ & & & \\
\hline MVA & & $\begin{array}{c}1.31 \\
(0.91)\end{array}$ & & \\
\hline$T^{\prime} s q$ & & & $\begin{array}{l}19.37 \\
(1.35)\end{array}$ & \\
\hline CFFO & & & & $\begin{array}{c}4.89 \\
(0.94)\end{array}$ \\
\hline Risk & $\begin{array}{l}67.41 \\
(2.15)\end{array}$ & $\begin{array}{l}83.75 \\
(3.07)\end{array}$ & $\begin{array}{l}85.75 \\
(3.63)\end{array}$ & $\begin{array}{l}81.56 \\
(3.49)\end{array}$ \\
\hline Tenure & $\begin{array}{l}26.72 \\
(3.02)\end{array}$ & $\begin{array}{l}24.03 \\
(3.33)\end{array}$ & $\begin{array}{l}25.81 \\
(3.39)\end{array}$ & $\begin{array}{l}25.68 \\
(3.13)\end{array}$ \\
\hline Title & $\begin{array}{l}17.54 \\
(2.97)\end{array}$ & $\begin{array}{l}16.11 \\
(3.47)\end{array}$ & $\begin{array}{l}16.79 \\
(3.39)\end{array}$ & $\begin{array}{l}17.13 \\
(3.58)\end{array}$ \\
\hline Lock & $\begin{array}{l}51.89 \\
(1.13)\end{array}$ & $\begin{array}{l}59.89 \\
(1.37)\end{array}$ & $\begin{array}{l}47.43 \\
(1.35)\end{array}$ & $\begin{array}{l}55.43 \\
(1.19)\end{array}$ \\
\hline$\%$ Own & $\begin{array}{l}37.32 \\
(2.89)\end{array}$ & $\begin{array}{l}36.87 \\
(2.81)\end{array}$ & $\begin{array}{l}33.39 \\
(2.84)\end{array}$ & $\begin{array}{l}35.81 \\
(2.87)\end{array}$ \\
\hline Age & $\begin{array}{l}36.33 \\
(2.73)\end{array}$ & $\begin{array}{l}44.38 \\
(2.14)\end{array}$ & $\begin{array}{l}45.91 \\
(2.51)\end{array}$ & $\begin{array}{l}40.62 \\
(2.60)\end{array}$ \\
\hline$T e n^{2}$ & $\begin{array}{l}-1.24 \\
(-3.84)\end{array}$ & $\begin{array}{l}-1.13 \\
(-3.76)\end{array}$ & $\begin{array}{c}-1.42 \\
(-3.74)\end{array}$ & $\begin{array}{l}-1.29 \\
(-3.81)\end{array}$ \\
\hline$\% O w n^{2}$ & $\begin{array}{l}-2.36 \\
(-3.14)\end{array}$ & $\begin{array}{l}-2.61 \\
(-3.29)\end{array}$ & $\begin{array}{l}-2.83 \\
(-3.71)\end{array}$ & $\begin{array}{l}-2.78 \\
(-3.58)\end{array}$ \\
\hline $\mathrm{Age}^{2}$ & $\begin{array}{l}-0.29 \\
(-2.13)\end{array}$ & $\begin{array}{l}-0.44 \\
(-2.17)\end{array}$ & $\begin{array}{l}-0.48 \\
(-2.14)\end{array}$ & $\begin{array}{l}-0.39 \\
(-2.17)\end{array}$ \\
\hline TAssets & $\begin{array}{c}0.01 \\
(1.17)\end{array}$ & $\begin{array}{c}0.01 \\
(0.64)\end{array}$ & $\begin{array}{c}0.01 \\
(0.91)\end{array}$ & $\begin{array}{c}0.01 \\
(0.88)\end{array}$ \\
\hline 2002 & $\begin{array}{c}5.81 \\
(0.49)\end{array}$ & $\begin{array}{c}6.03 \\
(0.52)\end{array}$ & $\begin{array}{c}6.36 \\
(0.57)\end{array}$ & $\begin{array}{c}5.94 \\
(0.50)\end{array}$ \\
\hline 2003 & $\begin{array}{c}1.49 \\
(0.24)\end{array}$ & $\begin{array}{c}1.68 \\
(0.27)\end{array}$ & $\begin{array}{c}1.79 \\
(0.30)\end{array}$ & $\begin{array}{l}1.57 \\
0.26\end{array}$ \\
\hline 2004 & $\begin{array}{c}5.81 \\
(0.96)\end{array}$ & $\begin{array}{c}6.34 \\
(1.09)\end{array}$ & $\begin{array}{c}6.71 \\
(1.15)\end{array}$ & $\begin{array}{c}6.03 \\
(1.02)\end{array}$ \\
\hline 2005 & $\begin{array}{l}-4.58 \\
(-0.76)\end{array}$ & $\begin{array}{l}-4.86 \\
(-0.84)\end{array}$ & $\begin{array}{c}-4.94 \\
(0.91)\end{array}$ & $\begin{array}{c}-4.62 \\
(-0.81)\end{array}$ \\
\hline 2006 & $\begin{array}{l}14.11 \\
(1.52)\end{array}$ & $\begin{array}{l}14.24 \\
(1.57)\end{array}$ & $\begin{array}{l}14.62 \\
(1.71)\end{array}$ & $\begin{array}{l}14.37 \\
(1.67)\end{array}$ \\
\hline
\end{tabular}


Exhibit 2 | (continued)

Regressions

\begin{tabular}{|c|c|c|c|c|}
\hline$\#$ & 1 & 2 & 3 & 4 \\
\hline Diversified & $\begin{array}{c}16.17 \\
(0.24)\end{array}$ & $\begin{array}{c}17.54 \\
(0.27)\end{array}$ & $\begin{array}{l}17.01 \\
(0.32)\end{array}$ & $\begin{array}{c}16.80 \\
(0.26)\end{array}$ \\
\hline Health Care & $\begin{array}{c}18.60 \\
(0.28)\end{array}$ & $\begin{array}{l}18.81 \\
(0.32)\end{array}$ & $\begin{array}{c}19.32 \\
(0.37)\end{array}$ & $\begin{array}{c}19.14 \\
(0.33)\end{array}$ \\
\hline Hotel & $\begin{array}{c}13.78 \\
(0.21)\end{array}$ & $\begin{array}{l}13.97 \\
(0.26)\end{array}$ & $\begin{array}{l}14.27 \\
(0.29)\end{array}$ & $\begin{array}{c}14.04 \\
(0.26)\end{array}$ \\
\hline Industrial & $\begin{array}{c}18.48 \\
(0.28)\end{array}$ & $\begin{array}{c}19.01 \\
(0.33)\end{array}$ & $\begin{array}{c}19.58 \\
(0.39)\end{array}$ & $\begin{array}{c}18.69 \\
(0.31)\end{array}$ \\
\hline Mall & $\begin{array}{c}17.77 \\
(0.26)\end{array}$ & $\begin{array}{l}18.25 \\
(0.31)\end{array}$ & $\begin{array}{l}18.61 \\
(0.35)\end{array}$ & $\begin{array}{c}17.93 \\
(0.27)\end{array}$ \\
\hline Office & $\begin{array}{r}116.55 \\
(1.26)\end{array}$ & $\begin{array}{r}118.13 \\
(1.36)\end{array}$ & $\begin{array}{r}121.49 \\
(1.45)\end{array}$ & $\begin{array}{r}116.97 \\
\quad(1.27)\end{array}$ \\
\hline Self-Storage & $\begin{array}{c}5.52 \\
(0.07)\end{array}$ & $\begin{array}{c}5.68 \\
(0.09)\end{array}$ & $\begin{array}{c}5.81 \\
(0.11)\end{array}$ & $\begin{array}{c}5.62 \\
(0.08)\end{array}$ \\
\hline Manufactured Homes & $\begin{array}{c}9.88 \\
(0.15)\end{array}$ & $\begin{array}{l}10.01 \\
(0.17)\end{array}$ & $\begin{array}{l}10.21 \\
(0.19)\end{array}$ & $\begin{array}{c}9.91 \\
(0.15)\end{array}$ \\
\hline Multi-Family & $\begin{array}{l}11.80 \\
(0.18)\end{array}$ & $\begin{array}{c}12.34 \\
(0.22)\end{array}$ & $\begin{array}{l}12.62 \\
(0.28)\end{array}$ & $\begin{array}{l}11.87 \\
(0.19)\end{array}$ \\
\hline Specialty & $\begin{array}{c}12.68 \\
(0.20)\end{array}$ & $\begin{array}{l}12.91 \\
(0.23)\end{array}$ & $\begin{array}{c}13.08 \\
(0.27)\end{array}$ & $\begin{array}{c}12.74 \\
(0.22)\end{array}$ \\
\hline$F$ & 4.89 & 5.01 & 5.23 & 4.98 \\
\hline Adj. $R^{2}$ & 67.13 & 68.04 & 68.71 & 67.89 \\
\hline \multicolumn{5}{|l|}{ Notes: } \\
\hline \multicolumn{5}{|c|}{$\begin{array}{l}\text { CSalary is the change in salary for } \mathrm{CEO}_{i} \text { in year } t \text {. Performance is measured by: TR3YR, the } \\
\text { average three-year total returns to shareholders; MVA is the firm's Market Value Added; T's } q \text { is } \\
\text { the ratio of the market value of the firm's equity and debt to the replacement cost of its assets; } \\
\text { CFFO is the change in funds from operations. Risk is the standard deviation of stock returns. } \\
\text { Tenure is how long the person served as CEO. Title is a dummy variable where } 1 \text { indicates the } \\
\text { CEO is also the chairman of the board and } 0 \text { otherwise. Lock is a dummy variable where } 1 \\
\text { indicates that the named officer is involved in a relationship requiring disclosure in the } \\
\text { "Compensation Committee Interlocks and Insider Participation" section of the proxy and } 0 \\
\text { otherwise. \%Own is the CEO's percentage ownership of the firm. Age is age of the CEO. TAsset is } \\
\text { total assets and is used to control for size. } f_{\text {Type }} \text { are property type dummies. tit are time dummies } \\
\text { for years } 2002-2006 \text {. }\end{array}$} \\
\hline
\end{tabular}


Exhibit 3 | Regressions

\begin{tabular}{|c|c|c|c|c|}
\hline & 1 & 2 & 3 & 4 \\
\hline Intercept & $\begin{array}{r}-181.12 \\
(-1.34)\end{array}$ & $\begin{array}{c}-180.41 \\
(-1.26)\end{array}$ & $\begin{array}{r}-133.52 \\
(-1.18)\end{array}$ & $\begin{array}{r}-174.23 \\
(-1.21)\end{array}$ \\
\hline TR3YR & $\begin{array}{l}14.36 \\
(3.41)\end{array}$ & & & \\
\hline MVA & & $\begin{array}{l}27.15 \\
(4.39)\end{array}$ & & \\
\hline$T^{\prime} s q$ & & & $\begin{array}{l}25.89 \\
(3.11)\end{array}$ & \\
\hline CFFO & & & & $\begin{array}{c}34.32 \\
(3.85)\end{array}$ \\
\hline Risk & $\begin{array}{r}122.36 \\
(0.87)\end{array}$ & $\begin{array}{r}155.83 \\
(1.41)\end{array}$ & $\begin{array}{c}181.75 \\
(1.27)\end{array}$ & $\begin{array}{c}156.31 \\
(1.46)\end{array}$ \\
\hline Tenure & $\begin{array}{c}0.93 \\
(0.04)\end{array}$ & $\begin{array}{l}23.78 \\
(0.67)\end{array}$ & $\begin{array}{c}6.88 \\
(0.17)\end{array}$ & $\begin{array}{l}19.83 \\
(0.45)\end{array}$ \\
\hline Title & $\begin{array}{r}241.32 \\
(0.98)\end{array}$ & $\begin{array}{l}92.03 \\
(0.48)\end{array}$ & $\begin{array}{c}113.94 \\
(0.48)\end{array}$ & $\begin{array}{l}98.46 \\
(0.51)\end{array}$ \\
\hline Lock & $\begin{array}{l}282.8 \\
(1.41)\end{array}$ & $\begin{array}{r}501.24 \\
(1.61)\end{array}$ & $\begin{array}{r}260.56 \\
(1.21)\end{array}$ & $\begin{array}{r}489.76 \\
(1.74)\end{array}$ \\
\hline$\%$ Own & $\begin{array}{l}35.13 \\
(0.72)\end{array}$ & $\begin{array}{c}39.62 \\
(0.73)\end{array}$ & $\begin{array}{c}1.87 \\
(0.03)\end{array}$ & $\begin{array}{l}43.87 \\
(0.68)\end{array}$ \\
\hline Age & $\begin{array}{l}61.69 \\
(2.49)\end{array}$ & $\begin{array}{l}41.81 \\
(2.14)\end{array}$ & $\begin{array}{l}41.81 \\
(1.96)\end{array}$ & $\begin{array}{l}43.52 \\
(2.31)\end{array}$ \\
\hline $\operatorname{Ten}^{2}$ & $\begin{array}{l}-1.37 \\
(-0.81)\end{array}$ & $\begin{array}{c}-1.74 \\
(-1.32)\end{array}$ & $\begin{array}{l}-0.97 \\
(-0.53)\end{array}$ & $\begin{array}{l}-1.67 \\
(-0.98)\end{array}$ \\
\hline$\% O w n^{2}$ & $\begin{array}{l}-1.59 \\
(-0.39)\end{array}$ & $\begin{array}{l}-2.13 \\
(-0.78)\end{array}$ & $\begin{array}{l}-0.02 \\
(-0.00)\end{array}$ & $\begin{array}{l}-1.93 \\
(-0.81)\end{array}$ \\
\hline $\mathrm{Age}^{2}$ & $\begin{array}{l}-5.64 \\
(-2.84)\end{array}$ & $\begin{array}{l}-3.92 \\
(-2.14)\end{array}$ & $\begin{array}{l}-3.74 \\
(-2.01)\end{array}$ & $\begin{array}{l}-3.88 \\
(-2.27)\end{array}$ \\
\hline TAssets & $\begin{array}{l}-0.02 \\
(-0.59)\end{array}$ & $\begin{array}{c}-0.02 \\
(-0.92)\end{array}$ & $\begin{array}{l}-0.06 \\
(-1.16)\end{array}$ & $\begin{array}{l}-0.03 \\
(-1.01)\end{array}$ \\
\hline 2002 & $\begin{array}{l}28.80 \\
(0.47)\end{array}$ & $\begin{array}{l}27.21 \\
(0.45)\end{array}$ & $\begin{array}{c}29.42 \\
(0.52)\end{array}$ & $\begin{array}{c}30.14 \\
(0.54)\end{array}$ \\
\hline 2003 & $\begin{array}{l}12.98 \\
(0.21)\end{array}$ & $\begin{array}{l}13.54 \\
(0.24)\end{array}$ & $\begin{array}{l}13.64 \\
(0.23)\end{array}$ & $\begin{array}{l}14.01 \\
(0.26)\end{array}$ \\
\hline 2004 & $\begin{array}{l}55.99 \\
(0.93)\end{array}$ & $\begin{array}{l}58.11 \\
(1.01)\end{array}$ & $\begin{array}{c}57.73 \\
(0.98)\end{array}$ & $\begin{array}{l}60.23 \\
(1.04)\end{array}$ \\
\hline 2005 & $\begin{array}{l}-49.79 \\
(-0.83)\end{array}$ & $\begin{array}{l}-47.81 \\
(-0.79)\end{array}$ & $\begin{array}{l}-52.16 \\
(-0.94)\end{array}$ & $\begin{array}{r}-45.47 \\
(0.95)\end{array}$ \\
\hline 2006 & $\begin{array}{c}40.32 \\
(0.67)\end{array}$ & $\begin{array}{l}44.71 \\
(0.71)\end{array}$ & $\begin{array}{l}44.10 \\
(0.69)\end{array}$ & $\begin{array}{c}42.94 \\
(0.68)\end{array}$ \\
\hline
\end{tabular}


Exhibit 3 | (continued)

Regressions

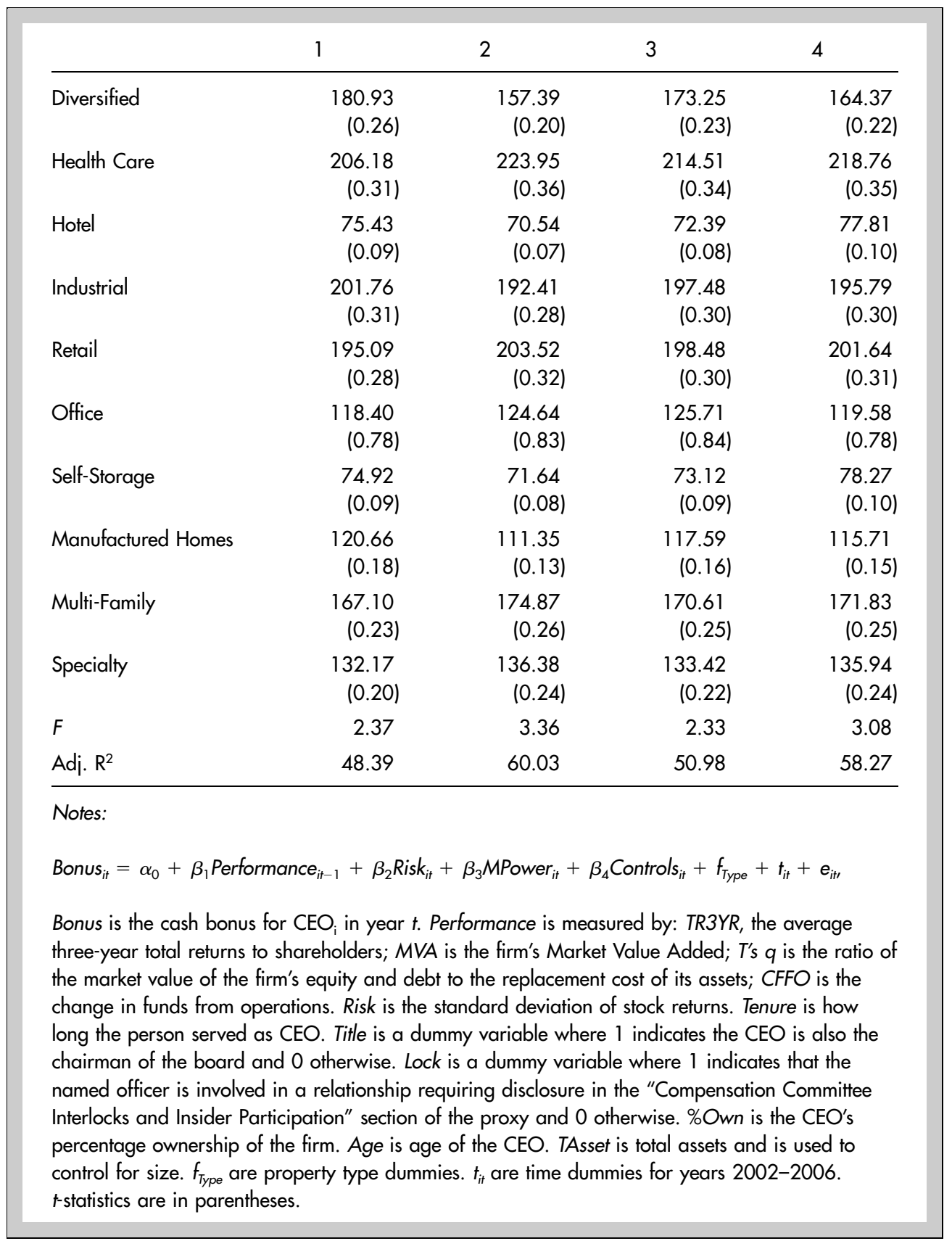


Exhibit 4 | Regressions

\begin{tabular}{|c|c|c|c|c|}
\hline & 1 & 2 & 3 & 4 \\
\hline Intercept & $\begin{array}{r}-492.81 \\
(-1.90)\end{array}$ & $\begin{array}{r}-598.16 \\
(-1.18)\end{array}$ & $\begin{array}{r}-367.46 \\
(-1.51)\end{array}$ & $\begin{array}{r}-556.48 \\
(-1.24)\end{array}$ \\
\hline TR3YR & $\begin{array}{l}13.42 \\
(3.16)\end{array}$ & & & \\
\hline MVA & & $\begin{array}{c}6.87 \\
(4.41)\end{array}$ & & \\
\hline$T^{\prime} s q$ & & & $\begin{array}{c}187.58 \\
(2.41)\end{array}$ & \\
\hline CFFO & & & & $\begin{array}{l}10.45 \\
(3.57)\end{array}$ \\
\hline Risk & $\begin{array}{l}14.84 \\
(2.38)\end{array}$ & $\begin{array}{l}36.28 \\
(2.73)\end{array}$ & $\begin{array}{l}33.14 \\
(2.23)\end{array}$ & $\begin{array}{l}38.47 \\
(2.49)\end{array}$ \\
\hline Tenure & $\begin{array}{c}22.56 \\
(0.59)\end{array}$ & $\begin{array}{l}46.15 \\
(1.05)\end{array}$ & $\begin{array}{l}34.17 \\
(0.90)\end{array}$ & $\begin{array}{l}41.64 \\
(1.02)\end{array}$ \\
\hline Title & $\begin{array}{r}-112.41 \\
(-0.48)\end{array}$ & $\begin{array}{r}-114.37 \\
(-0.49)\end{array}$ & $\begin{array}{r}-104.83 \\
(-0.49)\end{array}$ & $\begin{array}{r}-107.91 \\
(-0.48)\end{array}$ \\
\hline Lock & $\begin{array}{r}126.54 \\
(0.59)\end{array}$ & $\begin{array}{r}210.53 \\
(0.98)\end{array}$ & $\begin{array}{r}164.93 \\
(0.75)\end{array}$ & $\begin{array}{r}186.52 \\
(0.84)\end{array}$ \\
\hline$\%$ Own & $\begin{array}{l}55.01 \\
(1.12)\end{array}$ & $\begin{array}{c}47.72 \\
(0.71)\end{array}$ & $\begin{array}{l}23.09 \\
(0.36)\end{array}$ & $\begin{array}{l}49.33 \\
(0.81)\end{array}$ \\
\hline Age & $\begin{array}{l}53.34 \\
(2.41)\end{array}$ & $\begin{array}{l}33.59 \\
(1.47)\end{array}$ & $\begin{array}{l}34.18 \\
(1.51)\end{array}$ & $\begin{array}{l}40.58 \\
(1.76)\end{array}$ \\
\hline$T e n^{2}$ & $\begin{array}{l}-2.15 \\
(-1.71)\end{array}$ & $\begin{array}{l}-2.48 \\
(-1.42)\end{array}$ & $\begin{array}{l}-2.34 \\
(-1.19)\end{array}$ & $\begin{array}{l}-2.29 \\
(-1.26)\end{array}$ \\
\hline$\% O w n^{2}$ & $\begin{array}{l}-2.49 \\
(-0.83)\end{array}$ & $\begin{array}{l}-3.01 \\
(-0.79)\end{array}$ & $\begin{array}{c}-1.65 \\
(-0.44)\end{array}$ & $\begin{array}{l}-3.26 \\
(-0.84)\end{array}$ \\
\hline $\mathrm{Age}^{2}$ & $\begin{array}{l}-4.84 \\
(-2.36)\end{array}$ & $\begin{array}{l}-2.93 \\
(-1.46)\end{array}$ & $\begin{array}{l}-2.81 \\
(-1.52)\end{array}$ & $\begin{array}{l}-2.97 \\
(-1.94)\end{array}$ \\
\hline TAssets & $\begin{array}{l}-0.03 \\
(-0.68)\end{array}$ & $\begin{array}{l}-0.05 \\
(-1.40)\end{array}$ & $\begin{array}{l}-0.06 \\
(-1.21)\end{array}$ & $\begin{array}{l}-0.05 \\
(-0.97)\end{array}$ \\
\hline 2002 & $\begin{array}{l}29.10 \\
(0.47)\end{array}$ & $\begin{array}{l}27.61 \\
(0.45)\end{array}$ & $\begin{array}{l}27.59 \\
(0.45)\end{array}$ & $\begin{array}{c}23.69 \\
(0.38)\end{array}$ \\
\hline 2003 & $\begin{array}{l}18.91 \\
(0.31)\end{array}$ & $\begin{array}{l}16.18 \\
(0.26)\end{array}$ & $\begin{array}{l}16.12 \\
(0.26)\end{array}$ & $\begin{array}{l}11.28 \\
(0.18)\end{array}$ \\
\hline 2004 & $\begin{array}{l}63.42 \\
(1.05)\end{array}$ & $\begin{array}{l}59.35 \\
(0.98)\end{array}$ & $\begin{array}{l}59.44 \\
(0.98)\end{array}$ & $\begin{array}{c}56.79 \\
(0.83)\end{array}$ \\
\hline 2005 & $\begin{array}{l}37.89 \\
(0.62)\end{array}$ & $\begin{array}{l}43.02 \\
(0.71)\end{array}$ & $\begin{array}{l}43.24 \\
(0.71)\end{array}$ & $\begin{array}{c}45.61 \\
(0.75)\end{array}$ \\
\hline 2006 & $\begin{array}{l}66.05 \\
(1.09)\end{array}$ & $\begin{array}{l}71.56 \\
(1.18)\end{array}$ & $\begin{array}{l}71.67 \\
(1.18)\end{array}$ & $\begin{array}{r}71.33 \\
(1.18)\end{array}$ \\
\hline
\end{tabular}


Exhibit 4 | (continued)

Regressions

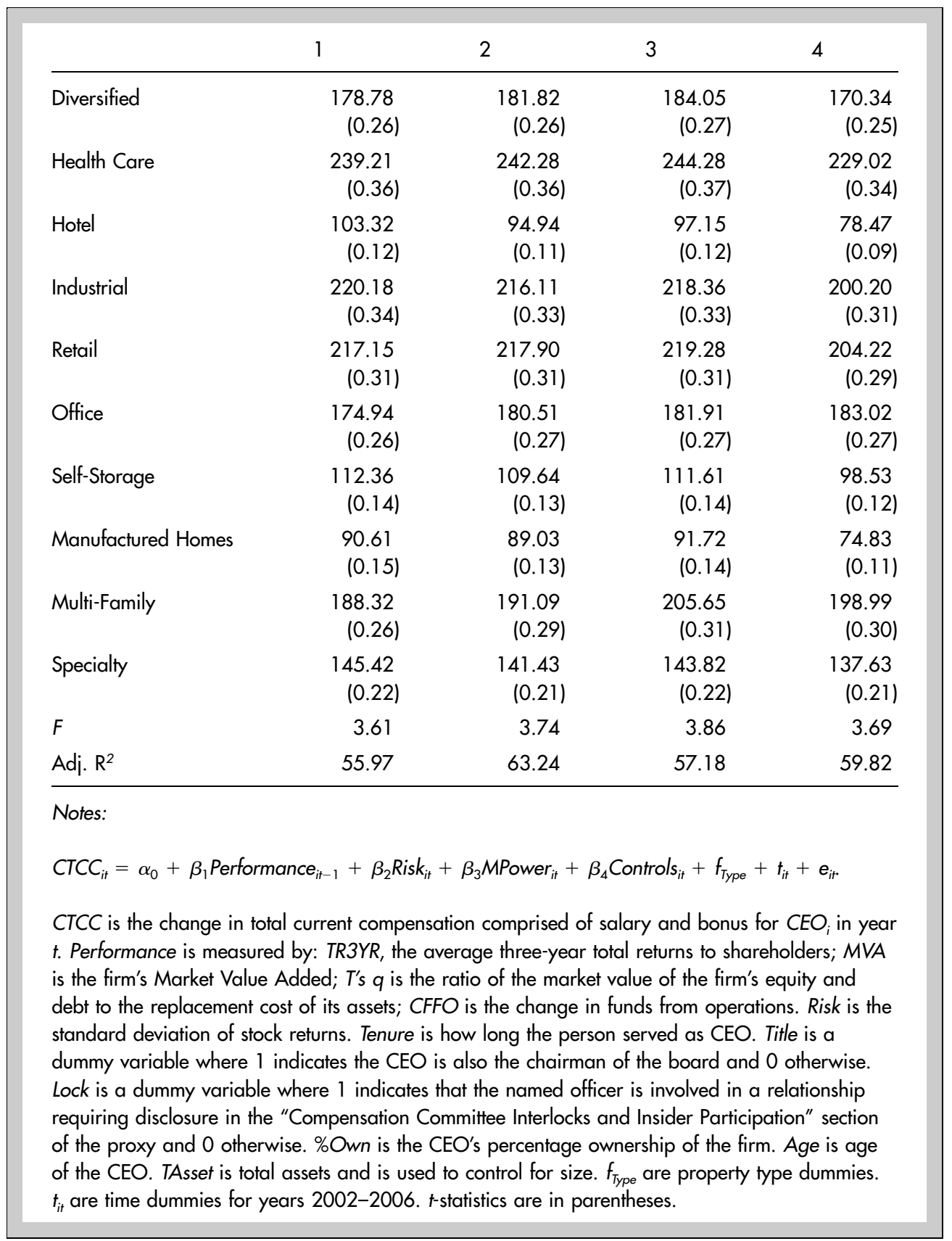


Exhibit 5 | Regressions

\begin{tabular}{|c|c|c|c|c|}
\hline & 1 & 2 & 3 & 4 \\
\hline Intercept & $\begin{array}{r}-117.04 \\
(-0.91)\end{array}$ & $\begin{array}{r}-337.97 \\
(-0.27)\end{array}$ & $\begin{array}{r}-374.60 \\
(-0.33)\end{array}$ & $\begin{array}{r}-301.59 \\
(-0.31)\end{array}$ \\
\hline TR3YR & $\begin{array}{l}20.54 \\
(3.66)\end{array}$ & & & \\
\hline MVA & & $\begin{array}{l}26.08 \\
(3.04)\end{array}$ & & \\
\hline$T^{\prime} s q$ & & & $\begin{array}{r}465.16 \\
(4.48)\end{array}$ & \\
\hline CFFO & & & & $\begin{array}{l}28.13 \\
(3.17)\end{array}$ \\
\hline Risk & $\begin{array}{r}184.70 \\
(0.92)\end{array}$ & $\begin{array}{r}205.67 \\
(1.06)\end{array}$ & $\begin{array}{r}282.50 \\
(1.58)\end{array}$ & $\begin{array}{r}200.98 \\
(1.01)\end{array}$ \\
\hline Tenure & $\begin{array}{l}11.65 \\
(0.22)\end{array}$ & $\begin{array}{l}18.77 \\
(0.04)\end{array}$ & $\begin{array}{l}30.23 \\
(0.64)\end{array}$ & $\begin{array}{l}19.68 \\
(0.13)\end{array}$ \\
\hline Title & $\begin{array}{r}-190.40 \\
(-0.60)\end{array}$ & $\begin{array}{r}-275.18 \\
(-0.89)\end{array}$ & $\begin{array}{r}-220.15 \\
(-0.77)\end{array}$ & $\begin{array}{r}-273.54 \\
(-0.84)\end{array}$ \\
\hline Lock & $\begin{array}{c}174.41 \\
(0.61)\end{array}$ & $\begin{array}{r}449.00 \\
(1.50)\end{array}$ & $\begin{array}{r}120.98 \\
(0.45)\end{array}$ & $\begin{array}{r}481.82 \\
(1.58)\end{array}$ \\
\hline$\%$ Own & $\begin{array}{r}169.86 \\
(2.06)\end{array}$ & $\begin{array}{c}125.31 \\
(1.46)\end{array}$ & $\begin{array}{r}127.95 \\
(1.96)\end{array}$ & $\begin{array}{r}114.64 \\
(1.39)\end{array}$ \\
\hline Age & $\begin{array}{r}552.39 \\
(1.71)\end{array}$ & $\begin{array}{r}507.93 \\
(1.65)\end{array}$ & $\begin{array}{r}455.76 \\
(1.62)\end{array}$ & $\begin{array}{r}498.76 \\
(1.70)\end{array}$ \\
\hline$T_{e n}^{2}$ & $\begin{array}{l}-1.61 \\
(-0.06)\end{array}$ & $\begin{array}{l}-4.66 \\
(-0.18)\end{array}$ & $\begin{array}{l}-1.26 \\
(-0.53)\end{array}$ & $\begin{array}{l}-5.03 \\
(-0.25)\end{array}$ \\
\hline Own ${ }^{2}$ & $\begin{array}{l}-8.34 \\
(-1.93)\end{array}$ & $\begin{array}{l}-5.73 \\
(-1.14)\end{array}$ & $\begin{array}{l}-6.60 \\
(-1.46)\end{array}$ & $\begin{array}{c}-5.23 \\
(-1.26)\end{array}$ \\
\hline $\mathrm{Age}^{2}$ & $\begin{array}{l}-5.00 \\
(-1.72)\end{array}$ & $\begin{array}{l}-4.68 \\
(-1.68)\end{array}$ & $\begin{array}{l}-4.23 \\
(-1.66)\end{array}$ & $\begin{array}{l}-4.86 \\
(-1.71)\end{array}$ \\
\hline TAssets & $\begin{array}{l}0.66 \\
(1.41)\end{array}$ & $\begin{array}{c}0.58 \\
(1.31)\end{array}$ & $\begin{array}{c}0.35 \\
(0.94)\end{array}$ & $\begin{array}{c}0.49 \\
(1.07)\end{array}$ \\
\hline 2002 & $\begin{array}{r}683.14 \\
(1.05)\end{array}$ & $\begin{array}{r}683.88 \\
(1.05)\end{array}$ & $\begin{array}{r}674.47 \\
(1.03)\end{array}$ & $\begin{array}{r}682.09 \\
(1.05)\end{array}$ \\
\hline 2003 & $\begin{array}{r}382.01 \\
(0.59)\end{array}$ & $\begin{array}{c}373.11 \\
(0.58)\end{array}$ & $\begin{array}{r}368.13 \\
(0.57)\end{array}$ & $\begin{array}{r}376.77 \\
(0.58)\end{array}$ \\
\hline 2004 & $\begin{array}{r}1,127.56 \\
(1.76)\end{array}$ & $\begin{array}{r}1,124.50 \\
(1.75)\end{array}$ & $\begin{array}{r}1,110.33 \\
\quad(1.73)\end{array}$ & $\begin{array}{r}1,126.77 \\
(1.76)\end{array}$ \\
\hline 2005 & $\begin{array}{r}593.36 \\
(0.92)\end{array}$ & $\begin{array}{r}619.54 \\
(0.96)\end{array}$ & $\begin{array}{r}566.32 \\
(0.88)\end{array}$ & $\begin{array}{r}577.13 \\
(0.90)\end{array}$ \\
\hline 2006 & $\begin{array}{r}1,066.37 \\
(1.66)\end{array}$ & $\begin{array}{r}1,082.91 \\
(1.69)\end{array}$ & $\begin{array}{r}1,039.58 \\
(1.62)\end{array}$ & $\begin{array}{r}1,050.46 \\
(1.64)\end{array}$ \\
\hline
\end{tabular}


Exhibit 5 | (continued)

Regressions

\begin{tabular}{|c|c|c|c|c|}
\hline & 1 & 2 & 3 & 4 \\
\hline Diversified & $\begin{array}{r}460.37 \\
(0.07)\end{array}$ & $\begin{array}{c}515.82 \\
(0.07)\end{array}$ & $\begin{array}{r}496.74 \\
(0.07)\end{array}$ & $\begin{array}{c}464.31 \\
(0.72)\end{array}$ \\
\hline Health Care & $\begin{array}{r}486.14 \\
(0.07)\end{array}$ & $\begin{array}{r}585.93 \\
(0.09)\end{array}$ & $\begin{array}{r}517.14 \\
(0.08)\end{array}$ & $\begin{array}{r}510.47 \\
(0.79)\end{array}$ \\
\hline Hotel & $\begin{array}{r}702.20 \\
(0.08)\end{array}$ & $\begin{array}{r}702.02 \\
(0.08)\end{array}$ & $\begin{array}{r}779.20 \\
(0.12)\end{array}$ & $\begin{array}{r}831.82 \\
(0.13)\end{array}$ \\
\hline Industrial & $\begin{array}{r}967.13 \\
(0.15)\end{array}$ & $\begin{array}{r}845.47 \\
(0.13)\end{array}$ & $\begin{array}{r}1,191.70 \\
(0.18)\end{array}$ & $\begin{array}{r}1,252.09 \\
(0.19)\end{array}$ \\
\hline Retail & $\begin{array}{r}299.92 \\
(0.04)\end{array}$ & $\begin{array}{r}252.49 \\
(0.04)\end{array}$ & $\begin{array}{r}260.26 \\
(0.04)\end{array}$ & $\begin{array}{c}314.31 \\
(0.05)\end{array}$ \\
\hline Office & $\begin{array}{r}346.79 \\
(0.05)\end{array}$ & $\begin{array}{r}380.27 \\
(0.06)\end{array}$ & $\begin{array}{c}356.71 \\
(0.05)\end{array}$ & $\begin{array}{r}348.95 \\
(0.05)\end{array}$ \\
\hline Self-Storage & $\begin{array}{r}245.27 \\
(0.03)\end{array}$ & $\begin{array}{c}264.72 \\
(0.04)\end{array}$ & $\begin{array}{r}235.64 \\
(0.04)\end{array}$ & $\begin{array}{c}246.02 \\
(0.04)\end{array}$ \\
\hline Manufactured Homes & $\begin{array}{l}96.16 \\
(0.01)\end{array}$ & $\begin{array}{c}175.15 \\
(0.03)\end{array}$ & $\begin{array}{r}171.76 \\
(0.03)\end{array}$ & $\begin{array}{c}164.91 \\
(0.02)\end{array}$ \\
\hline Multi-Family & $\begin{array}{r}186.40 \\
(0.03)\end{array}$ & $\begin{array}{r}184.85 \\
(0.03)\end{array}$ & $\begin{array}{r}214.81 \\
(0.03)\end{array}$ & $\begin{array}{r}204.09 \\
(0.03)\end{array}$ \\
\hline Specialty & $\begin{array}{r}174.76 \\
(0.03)\end{array}$ & $\begin{array}{r}240.17 \\
(0.04)\end{array}$ & $\begin{array}{r}218.93 \\
(0.03)\end{array}$ & $\begin{array}{r}233.16 \\
(0.04)\end{array}$ \\
\hline$F$ & 2.54 & 2.18 & 2.84 & 2.21 \\
\hline Adj. $R^{2}$ & 49.38 & 44.44 & 55.02 & 47.65 \\
\hline \multicolumn{5}{|l|}{ Notes: } \\
\hline \multicolumn{5}{|c|}{ 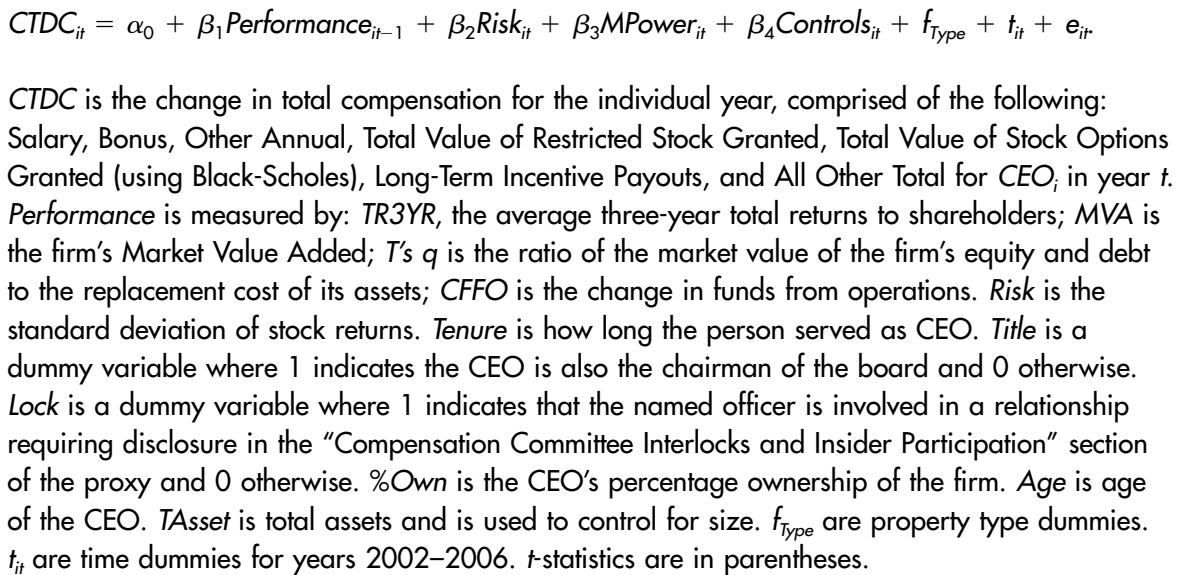 } \\
\hline
\end{tabular}


Exhibit 6 | Regressions

\begin{tabular}{|c|c|c|c|c|}
\hline & 1 & 2 & 3 & 4 \\
\hline Intercept & $\begin{array}{r}-748.19 \\
(-0.57)\end{array}$ & $\begin{array}{r}-191.24 \\
(-0.21)\end{array}$ & $\begin{array}{r}-117.81 \\
(-0.14)\end{array}$ & $\begin{array}{r}-204.87 \\
(-0.32)\end{array}$ \\
\hline TR3YR & $\begin{array}{l}13.55 \\
(2.41)\end{array}$ & & & \\
\hline MVA & & $\begin{array}{c}3.61 \\
(0.37)\end{array}$ & & \\
\hline$T^{\prime} s q$ & & & $\begin{array}{c}102.93 \\
(0.86)\end{array}$ & \\
\hline CFFO & & & & $\begin{array}{c}4.89 \\
(2.51)\end{array}$ \\
\hline Risk & $\begin{array}{l}92.37 \\
(0.58)\end{array}$ & $\begin{array}{l}50.49 \\
(0.28)\end{array}$ & $\begin{array}{l}76.09 \\
(0.33)\end{array}$ & $\begin{array}{c}58.71 \\
(0.41)\end{array}$ \\
\hline Tenure & $\begin{array}{r}108.14 \\
(2.33)\end{array}$ & $\begin{array}{r}103.58 \\
(2.03)\end{array}$ & $\begin{array}{l}92.97 \\
(1.97)\end{array}$ & $\begin{array}{r}115.67 \\
(1.98)\end{array}$ \\
\hline Title & $\begin{array}{c}583.81 \\
(2.01)\end{array}$ & $\begin{array}{r}622.74 \\
(1.97)\end{array}$ & $\begin{array}{c}630.11 \\
(1.89)\end{array}$ & $\begin{array}{r}600.53 \\
(2.04)\end{array}$ \\
\hline Lock & $\begin{array}{l}1,386 \\
\quad(5.23)\end{array}$ & $\begin{array}{l}1,528 \\
\quad(4.99)\end{array}$ & $\begin{array}{l}1,483 \\
\quad(4.84)\end{array}$ & $\begin{array}{l}1,621 \\
\quad(5.03)\end{array}$ \\
\hline$\%$ Own & $\begin{array}{c}8.03 \\
(0.10)\end{array}$ & $\begin{array}{c}9.65 \\
(0.08)\end{array}$ & $\begin{array}{c}5.54 \\
(0.05)\end{array}$ & $\begin{array}{c}8.42 \\
(0.08)\end{array}$ \\
\hline Age & $\begin{array}{r}187.58 \\
(0.62)\end{array}$ & $\begin{array}{r}123.82 \\
(0.46)\end{array}$ & $\begin{array}{r}126.78 \\
(0.45)\end{array}$ & $\begin{array}{r}125.34 \\
(0.56)\end{array}$ \\
\hline$T_{e n}^{2}$ & $\begin{array}{l}-4.93 \\
(-2.37)\end{array}$ & $\begin{array}{l}-4.87 \\
(-2.14)\end{array}$ & $\begin{array}{l}-4.29 \\
(-1.91)\end{array}$ & $\begin{array}{l}-4.95 \\
(-2.09)\end{array}$ \\
\hline$\% O w n^{2}$ & $\begin{array}{l}-1.19 \\
(-0.20)\end{array}$ & $\begin{array}{l}-1.06 \\
(-0.19)\end{array}$ & $\begin{array}{l}-1.01 \\
(-0.24)\end{array}$ & $\begin{array}{l}-1.08 \\
(-0.22)\end{array}$ \\
\hline$A g \mathrm{e}^{2}$ & $\begin{array}{l}-1.80 \\
(-0.69)\end{array}$ & $\begin{array}{l}-1.31 \\
(-0.48)\end{array}$ & $\begin{array}{l}-1.53 \\
(-0.52)\end{array}$ & $\begin{array}{l}-1.49 \\
(-0.57)\end{array}$ \\
\hline TAssets & $\begin{array}{c}0.02 \\
(0.82)\end{array}$ & $\begin{array}{c}0.02 \\
(0.20)\end{array}$ & $\begin{array}{c}0.02 \\
(0.31)\end{array}$ & $\begin{array}{c}0.02 \\
(0.25)\end{array}$ \\
\hline 2002 & $\begin{array}{r}603.89 \\
(1.81)\end{array}$ & $\begin{array}{r}617.76 \\
(1.85)\end{array}$ & $\begin{array}{r}614.57 \\
(1.84)\end{array}$ & $\begin{array}{r}628.10 \\
(1.88)\end{array}$ \\
\hline 2003 & $\begin{array}{r}445.02 \\
(1.35)\end{array}$ & $\begin{array}{r}466.38 \\
(1.42)\end{array}$ & $\begin{array}{r}459.10 \\
(1.39)\end{array}$ & $\begin{array}{r}479.61 \\
(1.45)\end{array}$ \\
\hline 2004 & $\begin{array}{r}1,021.49 \\
(3.13)\end{array}$ & $\begin{array}{r}1,048.95 \\
(3.22)\end{array}$ & $\begin{array}{r}1,035.62 \\
3.17\end{array}$ & $\begin{array}{r}1,059.83 \\
(3.25)\end{array}$ \\
\hline 2005 & $\begin{array}{r}1,156.00 \\
(3.54)\end{array}$ & $\begin{array}{r}1,210.94 \\
(3.71)\end{array}$ & $\begin{array}{r}1,166.42 \\
(3.56)\end{array}$ & $\begin{array}{r}1,222.56 \\
(3.74)\end{array}$ \\
\hline 2006 & $\begin{array}{r}1,631.88 \\
(5.01)\end{array}$ & $\begin{array}{r}1,683.20 \\
(5.17)\end{array}$ & $\begin{array}{r}1,643.12 \\
(5.04)\end{array}$ & $\begin{array}{r}1,693.92 \\
(5.20)\end{array}$ \\
\hline
\end{tabular}


compensation. First, the results show that lagged performance, no matter how defined, does not significantly influence CSalary. This result is not surprising since CEOs might be compensated for performance in other ways. Riskiness of the firm, how long the CEO has served, whether they served as both CEO and chairman of the board, and their ownership position are found to influence CSalary. Firm risk has a significant, positive effect on CSalary. ${ }^{11}$ This may reflect differences in the required ability of the CEO. As expected, the measures of Power, Tenure, Title, and PctOwn have significant positive effects on CSalary. ${ }^{12}$ These findings suggest that as CEOs consolidate their power, they use it to influence the change in their salaries. Thus, a potential agency problem is indicated. As expected, Age has a positive effect on CSalary. Gibbons and Murphy (1992) find that as CEOs approach retirement, their salaries are boosted to raise retirement income. In addition, if $A g e$ serves as a good proxy for experience, it should have a positive effect on CSalary. The negative coefficients for Tenure ${ }^{2}, P_{c t O} w^{2}$, and $A g e^{2}$ show that Tenure, PctOwn and Age positively affect CSalary but at a decreasing rate. The negative coefficient for PctOwn ${ }^{2}$ suggests that at some level of ownership, CSalary declines. The results indicate that neither property type nor length of service affects CSalary.

\section{Bonus}

Exhibit 3 contains the results for BONUS. A bonus is normally paid as a reward for performance above the norm, as well as independent of the prior year's bonus and is not cumulative. All models are statistically significant and have high explanatory power. First, all four definitions of performance have significantly positive influences on BONUS. This is as expected and in line with Scott, Anderson, and Loviscek (2001). This finding also suggests that BONUS is a reward for performance. Contrary to Scott, Anderson, and Loviscek, age has a significantly positive influence on $B O N U S$, but firm size does not. The influence of age on BONUS is consistent with age serving as a proxy for experience. Alternatively, it could indicate that older CEOs require greater bonus compensation to motivate them to make decisions that are consistent with shareholders' wealth maximization. The proxies for managerial power have no significant influence on BONUS. This is likely the result of CEOs using their power to structure their compensation so that it includes a smaller risk-based component. Although not shown in Exhibit 3, just as Hardin (1998) found, Time (the year the bonus is awarded) is significant, which leads to the conclusion that the changes over the years 2000 through 2006 influenced BONUS.

\section{Change in Cash Compensation}

Exhibit 4 contains the results for $C T C C$. As before, all the models are significant and have high explanatory power. The results indicate firm performance and risk impact CTCC. Surprisingly, MPower ${ }_{i t}$, Age, and Total Assets do not significantly influence CTCC. Age's lack of influence contrasts with the Pennathur and Shelor 
(2002) findings. The finding that Total Assets is insignificant also differs from Chopin, Dickens, and Shelor (1995), Hardin (1998), and Scott, Anderson, and Loviscek (2001). Again, as found by Hardin (1998), Time (the year of the compensation) is significant, leading to the conclusion that the changes over the years 2000 through 2006 influenced CEOs' CTCC.

\section{Change in Total Compensation}

Exhibit 5 contains the results for $C T D C$. Again, all the models are significant and have high explanatory power. As expected, Performance ${ }_{i t-1}$ and $\% O w n$ have significant positive effects on $C T D C$, and all four measures of performance are significant. Ownership is the only proxy for managerial power that has a significant influence, and its influence is increasing but at a decreasing rate. Thus, it appears that CEOs are using their power to influence CTDC. The impact of Age on $C T D C$ is positive but marginal. This finding differs from Pennathur and Shelor (2002), who find that age has a negative influence. In contrast to previous studies, size does not have a significant influence.

\section{Option Awards}

Lastly, Exhibit 6 contains the results for the total real value of stock options granted during the year using Black Scholes option valuation methodology, $B L K V A L$. Once more, all the models are significant and have high explanatory power. TR3YR (average three-year total returns to shareholders) and CFFO (change in funds from operations) are the only measures of performance that have a significant positive influence on BLKVAL. One may interpret the finding that option awards are driven by both the increasing of shareholders' wealth and the improvement operating performance. This indicates that option awards serve their intended purpose of aligning the interests of management and shareholders. MVA and Tobin's $q$ are insignificant. This is unexpected, because these measures are indicators of shareholder wealth maximization and managerial performance, and stock option awards are normally granted to reward managerial performance. The finding of a positive relationship between $B L K V A L$ and stock returns is consistent with other studies (Hall and Liebman, 1998) and incentive income and stock returns (Scott, Anderson, and Loviscek, 2001). The significance of CFFO is in agreement with Pennathur, Gilley, and Shelor (2005). However, the finding of a positive relationship between $B L K V A L$ and stock returns contrasts with Pennathur, Gilley, and Shelor. They conclude that their finding of a negative relationship is because stock options are being awarded to better align CEO interest with that of stockholders after the firm suffers losses. However, perhaps their conclusion is time sensitive, as their sample time period is from 1997 to 2000, a period of falling REIT returns. In contrast, the sample time period considered in this study is 2000-2006, a period of positive and negative REIT returns. In addition, three measures of managerial power-tenure, title, and interlock-have a significantly positive effect on BLKVAL. Thus, the more power the CEO has, the larger 
BLKVAL. Risk and Total Assets do not have a significant effect. This finding implies that CEOs are not awarded options for investing in high-risk projects or for simply increasing the size of the REIT. This differs with Pennathur, Gilley, and Shelor's (2005) conclusion.

\section{Summary and Conclusions}

This study explores the change in REIT CEO compensation. Five different forms of change in CEO compensation are considered: change in CEO salary, cash bonuses, change in CEO salary plus bonus (change in total cash compensation), change in CEO total compensation, and stock options granted. To capture the determinants of the change in CEO compensation, the following performance measures are employed: the average three-year total return to shareholders, market value added, Tobin's q, and the change in funds from operations. The impact of managerial power on the change in compensation is also examined. A panel data set is used to capture both the time-series and cross-sectional effects. All the models are significant and have high explanatory power.

The findings indicate that performance and size do not influence change in CEO salary. Alternatively, risk, tenure, title, ownership, and age all affect change in CEO salary. Thus, CEO power and experience have a significant impact on the change in CEO salary and as firm risk increases, more expertise is needed to manage the REIT. As expected, performance and experience drive cash bonuses. In contrast to expectations and previous studies, cash bonuses are not influenced by risk, CEO power, or size. The change in total cash compensation is significantly influenced by firm performance and risk. CEOs are rewarded for performance and risk taking. Surprisingly, power, age, and size do not significantly influence the change in total cash compensation. The latter findings are in contrast to those of previous studies. Performance and ownership have significant impacts on changes in total CEO compensation, while age has a marginal effect. These results confirm that compensation committees consider REIT performance important when deciding the CEO's total compensation package.

The data show that CEO option awards are linked to stockholder returns. This is similar to Hall and Liebman (1998) and Scott, Anderson, and Loviscek (2001), who find that option awards and incentive compensation are positively related to stock returns. This finding is in stark contrast to Pennathur, Gilley, and Shelor (2005), who find that option awards are inversely related to stock returns. Further, the granting of stock options is affected by CEO tenure in office, when they are both CEO and chairman of the board, and when CEOs have interlocking relationships that require disclosure. These findings suggest CEOs are using their power to affect the granting of stock options. Contrary to Pennathur, Gilley, and Shelor, the findings in this study do not indicate that firm risk influences grants of stock options. Similar to Pennathur, Gilley, and Shelor, size and age are not found to affect the grants of stock options. The change in the different forms of CEO compensation, except for change in CEO salary, is significantly influenced

\begin{tabular}{|c|c|c|}
\hline$J R E R$ & Vol. 33 & $\mathrm{No.} 2-201$ \\
\hline
\end{tabular}


by REIT performance. On a cautionary note, the significance of the proxies for CEO power may be an indication of the existence of agency problems.

\section{Endnotes}

${ }^{1}$ For a survey of the corporate literature see, Core, Guay, and Larcker (2003).

${ }^{2}$ MVA and CFFO are correlated with Total Assets (size) but not significantly. In addition, the variance inflation factors between MVA and CFFO and Total Assets are 1.28 and 1.45 respectively, which indicates collinearity is not a problem. Additionally, Total Assets was not significant when the models were run with the MVA and CFFO excluded.

${ }^{3}$ Surveys of the corporate compensation literature include Murphy (1999) and Core, Guay, and Larcker (2003). More recent works in this area include Gius (2007) and Tzioumis (2008). Evidence of the continued expansion of the existing REIT specific literature is found in Sirmans, Friday, and Price (2006), Daniels and Phillips (2007), Ooi, Webb, and Zhou (2007), and Hardin, Hill and Hoper (2009).

${ }^{4}$ The correlation matrix indicated that some variables are significantly correlated. Subsequently, variance inflation factors were calculated to determine if multicollinearity was a significant problem within the model. None of the variance inflation factors exceeded 1.5, indicating that multicollinearity is not adversely influencing the coefficient estimates.

5 The Shapiro-Wilk W test for normal data and the Skewness/Kurtosis test for normality were run for each year and for each form of compensation and normality was not rejected at the $5 \%$ level.

${ }^{6}$ Tenure and Age are significantly correlated. However, the variance inflation factor for the two variables is 1.42 , indicating that collinearity is not a problem.

7 To verify that BONUS and BLKVAL are independent of the prior year's BONUS and $B L K V A L$, the regressions were run with BONUS and BLKVAL lagged as independent variables and neither was found to be significant.

8 The Shapiro-Wilk W test for normal data and Skewness/Kurtosis test for normality were run for each year and for each form of compensation and normality was not rejected at the $5 \%$ level.

9 Tobin's q is calculated using Han (2006).

${ }^{10}$ Hausman test statistic: $\chi^{2}=17,790.03$.

${ }^{11}$ Risk is the standard deviation of the firm's stock returns of the previous year.

12 To investigate the presence of collinearity in the models, each predictor variable is regressed against all others. The average $R^{2}$ is .20. Next, the relation between the predictor variables was determined using the variance inflation factors (VIF). The average VIF is 1.46 . A VIF greater than 10 may be a signal of collinearity problems. Thus, collinearity is not significant.

\section{References}

Baumol, W.J. Business Behavior, Value and Growth. New York: MacMillan, 1959.

Chopin, M.C., R.N. Dickens, and R.M. Shelor. An Empirical Examination of Compensation of REIT Managers. Journal of Real Estate Research, 1995, 10, 263-68. 
Core, J.E., W.R. Guay, and D.F. Larcker. Executive Equity Compensation and Incentives: A Survey. Economic Policy Review, 2003, 9, 27-50.

Daniels, K. and R.A. Phillips. The Valuation Impacts of Financial Advisors: An Empirical Analysis of REIT Mergers and Acquisitions. Journal of Real Estate Research, 2007, 29:1, $58-74$.

Ertugrul, M., O. Sezer, and C.F. Sirmans. Financial Leverage, CEO Compensation, and Corporate Hedging: Evidence from Real Estate Investment Trusts. Journal of Real Estate Finance and Economics, 2008, 36:1, 53-80.

Feng, Z., C. Ghosh, and C.F. Sirmans. Director Compensation and CEO Bargaining Power in REITs. Journal of Real Estate Finance and Economics, 2007, 35:3, 225-51.

Gibbons, R. and K.J. Murphy. Optimal Incentive Contracts in the Presence of Career Concerns: Theory and Evidence. The Journal of Political Economy, 1992, 100, 468-505.

Ghosh, C. and C.F. Sirmans. Board Independence, Ownership Structure and Performance: Evidence from Real Estate Investment Trusts. Journal of Real Estate Finance and Economics, 2003, 26, 287-318.

On REIT CEO Compensation: Does Board Structure Matter? Journal of Real Estate Finance and Economics, 2005, 30, 397-428.

Ghosh, C., J.P. Harding, O. Sezer, and C.F. Sirmans. The Role of Executive Stock Options in REIT Repurchases. Journal of Real Estate Research, 2008, 30:1, 27-44.

Gius, M. Using Panel Data to Estimate the Economic Determinants of CEO Compensation. Review of Applied Economics, 2007, 3:1-2, 79-89.

Hall, B.J. and J.B. Liebman. Are CEOS Really Paid Like Bureaucrats? The Quarterly Journal of Economics, 1998, 113, 653-91.

Han, B. Insider Ownership and Firm Value: Evidence from Real Estate Investment Trusts. Journal of Real Estate Finance and Economics, 2006, 32, 471-93.

Hardin, III, W.G. Executive Compensation in EREITs: EREIT Size is but One Determinant. Journal of Real Estate Research, 1998, 16, 401-10.

Hardin, III, W.G., M.D. Hill, and J.J. Hopper. Ownership Structure, Property Performance, Multifamily Properties, and REITs. Journal of Real Estate Research, 2009, 31:3, 285-306.

Jensen, M.C. and W.H. Meckling. Theory of the Firm: Managerial Behavior, Agency Costs and Ownership Structure. Journal of Financial Economics, 1976, 3, 305-60.

Murphy, K. Executive Compensation. In: O. Ashenfelter, and D. Card (eds.), Handbook of Labor Economics. Vol. 3B. Amsterdam: North-Holland, 1999.

Pennathur, A.K., O.W. Gilley, and R.M. Shelor. An Analysis of REIT CEO Stock-Based Compensation. Real Estate Economics, 2005, 33, 189-202.

Pennathur, A.K. and R.M. Shelor. The Determinants of REIT CEO Compensation. Journal of Real Estate Finance and Economics, 2002, 25, 99-113.

Ooi, J.T.L., J.R. Webb, and D. Zhou. Extrapolation Theory and the Pricing of REIT Stocks. Journal of Real Estate Research. 2007, 29:1, 27-57.

Rose, N.L. and A. Shepard. Firm Diversification and CEO Compensation: Managerial Ability or Executive Entrenchment? The RAND Journal of Economics, 1997, 28, 489-514.

Rosen, S. Authority, Control, and the Distribution of Earnings. The Bell Journal of Economics, 1982, 13, 311-23.

Scott, J.L., R.I. Anderson, and A.L. Loviscek. Are REIT CEOs Rewarded for Performance? Another Look. Journal of Real Estate Portfolio Management, 2001, 7, 247-52.

\begin{tabular}{l|l|lllll} 
JRER & $\mathrm{V} \circ \mathrm{I} .33$ & $\mathrm{~N} \circ .2-2$ & 0 & 1 & 1
\end{tabular}


Sirmans, G.S., H.S. Friday, and R.M. Price. Do Management Changes Matter? An Empirical Investigation of REIT Performance. Journal of Real Estate Research, 2006, 28: 2, 131-48.

Smith, C.W. Jr. and R.L. Watts. The Investment Opportunity Set and Corporate Financing, Dividend, and Compensation Policies. Journal of Financial Economics, 1992, 32, 263-92.

Tzioumis, K. Why Do Firms Adopt CEO Stock Options? Evidence from the United States. Journal of Economic Behavior and Organization, 2008, 68:1, 100-11.

Vincent, L. The Information Content of Funds from Operations (FFO) for Real Estate Investment Trusts (REITs). Journal of Accounting and Economics, 1999, 26, 69-104.

Willis, R.J. Wage Determinants: A Survey and Reinterpretation of Human Capital Earnings Functions. Economics Research Center/NORC, Chicago, IL, 1985.

John M. Griffith, Old Dominion University, Norfolk, VA 23529 or jgriffit@odu.edu. Mohammad Najand, Old Dominion University, Norfolk, VA 23529 or manajand@ odu.edu.

H. Shelton Weeks, Florida Gulf Coast University, Fort Myers, FL 33965-6565 or sweeks@fgcu.edu. 